\title{
ANALYSIS OF INSURANCE COMPANIES OPERATING IN SLOVAKIA IN TERMS OF FLOOD RISK INSURANCE
}

\author{
M. MADAJOVÁ \& L'. SOLÍN \\ Institute of Geography, Slovak Academy of Sciences, Bratislava, Slovakia.
}

\begin{abstract}
Analysis of the trends and spatial variability of flood insurance coverage in Slovakia pointed to the decreasing interest of people in property insurance against flood risk. There are several causes for this. One of them possibly lies in the conditions of insurance companies concerning flood risk insurance, which among other things also specify limits and exclusions from insurance. The majority of the insured are not aware of these facts at the time of signing the contract and the rejection or reduction of payments for flood damage is then a source of frustration. The paper analyses flood insurance conditions in all insurance companies in Slovakia, which offer building and contents insurance in terms of five aspects: (1) definition of concepts connected with flood hazard, (2) inclusion of flood risk into insurance modules of companies, (3) scope of property which is the object of the insurance, (4) exclusions and limits to flood risk insurance, and (5) the amounts of the premiums and claims.
\end{abstract}

Keywords: exclusions, flood, flood hazard insurance, limits, premium.

\section{INTRODUCTION}

The strategy for the mitigation of negative consequences caused by floods is one of important components of integrated flood risk management [1]. It is the Government and insurance companies that play the principal role in this sense [2-8]. In many countries, there is no strict legal duty for governments to provide assistance for flood damage. In the Slovak Republic (SR), the legislative system does not impose on the government the obligation of participating in the compensation of damage caused by flooding to people and firms, but it may provide, especially in case of massive damage caused by flooding, a non-recurring financial contribution to affected persons. Therefore, private insurance companies play a more important role in the strategy of mitigation of negative consequences caused by floods. There are 14 insurance companies active in Slovakia [9] that insure buildings and household content in the sphere of non-life insurance. Their market share is shown in Table 1.

Analysis of the trends and spatial variability of flood risk insurance in Slovakia [11] based on data provided by the Allianz-Slovak Insurance Company for the period 2002-2011 points to a comparatively distinct decreasing interest of people in property insurance against floods. For instance, as of the end of 2011, only $54.4 \%$ of insurance policies were active against the situation in 2002. This decrease can be attributable to several causes. Madajová et al. [12] point to, for instance, the socio-economic status of the population and the general discontent of the insured with the compensation amounts. The essential reason is also the refusal of insurers to provide any compensation. This leads to frustration and distrust that the insurance company will not compensate the real cost of damage liquidation. These statements were also confirmed by empirical findings obtained by questionnaire survey, which was concerned four 
Table 1: Market share of Slovak insurance companies in non-life insurance.

\begin{tabular}{ll}
\hline Insurance companies & Market share (\%) on 31/12/2013 \\
\hline Aegon & $\mathrm{x}$ \\
Allianz & 34.87 \\
Astra & $\mathrm{x}$ \\
Axa & 1.59 \\
ČSOB & 2.89 \\
Ergo & 0.2 \\
Generali & 10.05 \\
Groupama & 0.38 \\
Komunálna poist'ovňa & 6.45 \\
Kooperatíva & 26.73 \\
Poštová banka & 0.12 \\
Union & 3.32 \\
Uniqa & 8.01 \\
Wüstenrot & 2.35 \\
\hline
\end{tabular}

$\mathrm{x}$ : not specified (insurance companies not active in non-life insurance in 2013)

Source: Slovak Insurance Association [10]

aspects of flood risk: (i) flood hazard and flood damage, (ii) individual flood protection, (iii) flood hazard awareness, (iv) economic and social vulnerability. The questionnaire survey was conducted during June - July 2015 in six municipalities (3,082 households) located in the upstream basins of Myjava river.

We consider that the discontent of the population with the insurance claim is due to the fact that people do not thoroughly read the general and specific insurance conditions (ICs), which contain the limiting factors of insurance claims and their amounts. The general ICs of companies operating in SR are as a rule similar, but the insurance coverage and compensation of damage caused by floods depends on the specific conditions concerning the risk of flooding, which are different in each company. The majority of insurance companies in the period between 2010 and 2014 (after the extreme flood events of 2010) updated their ICs for property insurance.

The aim of this article is to analyse the ICs of companies operating in the SR insurance market in terms of building and household content insurance against risk of flooding. The ICs are available online on the websites of individual insurance companies. All insurance companies were also approached individually to give us additional information about the flood risk insurance (for examle, whether they use the flood maps or they use own database about the flood insurance events, what other criteria are applied when deciding on property insurance against the risk of flooding, how they differentiated the insurance premium). The analysis is focused on five basic aspects that should be paid attention to at the moment of contracting property insurance, especially if the person arranges the policy in order to insure damage caused by flood hazard. The first aspect is the definition of flooding itself in ICs and its compliance with the definition of flooding in the literature and legislative standards of the SR. The second and third aspects are the inclusion of flood risk into the insurance modules of the company and the scope of property that is the object of insurance. A very important aspect in terms of insurance claims is that of exclusions and limits to flood risk insurance. The amount 
of the premiums, as well as of the claims in the case of an insured event, also plays a crucial role when deciding to conclude an insurance policy. The final remarks sum up the obtained results.

The results of the analysis are expected to help better orientate the population in ICs concerning flood risk and to provide them with a rational basis for their expectations in the case of damage caused by flooding.

\section{DEFINITION OF FLOOD}

The definition of the term flood in ICs of companies should be based on the interpretation of this concept in the scientific literature or on the definition of flooding in the legislative system of the SR. The agreement of the definition of flooding on the science-legislation-insurance axis reduces the risk of different conflicts that may arise due to vague interpretation of the term flood. Before the detailed analysis of the term flood in ICs of companies, a brief commentary on the interpretation of this concept in the scientific literature and the legal system of the SR will be provided.

\subsection{Scientific literature}

Flooding is considered a natural phenomenon caused first of all by climatic factors (rain, snow and ice melt, ice jams). Apart from the main causes of floods, local flood-intensifying factors also play an important role. Ward and Robinson [13] and Smith and Ward [14], for instance, classify them into four groups: (a) stable basin factors - area, shape, slope, aspect, altitude; (b) variable basin factors - climate, geology, soil type, vegetation cover, anthropogenic influences on storage capacity, infiltration, and transmissivity; (c) drainage network factors; (d) channel factors. Therefore, there are various definitions of flooding in the literature. Some of them are limited to the process of overflowing, for example:

'A flood is a relatively high flow which overtaxes the natural channel provided for the runoff' [15].

Other definitions interpret flooding in a broader sense:

\section{'A flood is body of water which rises to overflow land which is not normally submerged' [16].}

This means that apart from the overflow, flooding of a territory can also be caused by processes such as flat areas being flooded by heavy rainfall ponding on the surface, sheet overland flow on slopes, or the groundwater table rising above the level of the ground surface, etc., due to which areas outside the floodplains are also flooded.

Floods are normally classified into several types in terms of factors that participate in their origin and the scope of flooding: (i) river or regional floods: the natural overflow of a stream due to long-lasting rainfall or snow melt occurring in a number of streams; (ii) flash floods: local floods, originally caused by excessively heavy rainfall, and/or intense snow and ice melt. Apart from the overflow of the river bank, there is also overland flow on slopes that threatens structures and objects outside the floodplain zone; (iii) ice-jam floods: impoundment of the water table and overflow due to ice in the river channel; (iv) inner floods: flooding of a territory by surface waters that did not soak into the soil and that had no natural outflow or the rise of groundwater to the surface; and (v) floods as a consequence of the disruption of water management objects: flooding of a territory due to overflow, seepage, or dam/dam wall failure. Different types of floods fall under the common term of flood hazard. 


\subsection{Legislative system of the SR}

The legislative system of the SR defined the term flood in Act No. 71/2015 [17], but in time when the majority of insurance companies defined their ICs, that is, in the years 2010-2014, Act No. 7/2010 [18] was in force. This Act (\$ 2, clause 1) defined a flood as the temporary inundation of a territory, which is not usually covered by water. A flood occurs when:

a. The water table of a stream temporarily significantly increases and there is the hazard of overflow or water has already overflowed;

b. Natural runoff of precipitation or snow melt waters into the recipient is temporarily blocked and inner waters flood a territory. Inner waters are those that occur in the territory protected by dams or counter-flood lines, especially waters that cannot flow out in a natural way because of increased water table in a recipient; water brought by intensive precipitation or snow melt in the territory with no option of runoff via a stream;

c. There is a hazard of overflow of a stream or water has already overflowed due to ice drift, ice-jam, or other obstructions in channel, bridges, and locks or in the inundated area;

d. The area is flooded due to intensive rainfall or accumulation of water from snow melt;

e. The protected area (area protected by a water management structure) is flooded due to increased groundwater table surfacing, which causes a long-lasting high water level in a stream;

f. There is hazard of overflow or the stream has already overflowed due to a crash or defect in a water management structure.

\subsection{Insurance conditions (ICs) of insurance companies}

Flood hazard is expressed in the ICs of all companies in two terms: flood (F) and inundation (I). The term flood appears in three variants:

- F is flooding of the insured place by water that has naturally overflowed the banks of water streams/water reservoirs or broken these banks. In the case of a watercourse enclosed by dikes, the bank means the body of the dike (Allianz, Astra, ČSOB, Groupama, Union, Wüstenrot).

- F means flooding of territories by water that has overflowed the banks of streams or water reservoirs or which has broken the banks and dikes or the flooding has been caused by an abrupt and accidental diminishment of the discharge profile of the stream (Aegon, Generali, Ergo, Komunálna poist'ovňa, Kooperativa, Uniqa);

- $\mathrm{F}$ is a temporary distinct increase of the water table in a stream or other surface waters when water floods the area beyond the stream channel and causes damage (Axa, Poštová banka); this also applies in the cases when water cannot outflow in a natural way from a certain area due to the perturbed stability of a stream (Poštová banka).

Varied interpretations of the term inundation also appear in the conditions of insurance companies:

- I is the formation of a continuous water area, which is either standing or flowing for some time over the insured place (Aegon, Generali, Komunálna poistovňa, Kooperativa); 
- I is a phenomenon caused by natural effects results in the formation of a continuous water area, which is either standing or flowing for some time over the insured place (Allianz, Astra, Grupama, Union, Wüstenrot). Union quotes that the facts of where the water is from, how it penetrated the insured place, and how it caused the damage (rainfall, snow melt, backwater of groundwater level, and the like) are not decisive.

- I is the formation of a continuous water area that is standing or flowing for some time without natural outflow at the insured place (Poštová banka);

- I is the formation of a continuous standing or flowing water area on the ground at the insured place where there is no natural outflow and that has been caused by natural effects (Axa)/atmospheric precipitation $(\breve{C} S O B) /$ atmospheric precipitation, snow, and/or ice melt (Ergo).

- I is the formation of a continuous water area in the insured place that was caused by increased surface waters (standing or flowing) of a channel or by atmospheric precipitation (Uniqa). This definition is remarkable for its ambiguity because the phrase increase of surface water of its channel' is already incorporated in the definition of flood.

The reason why the term inundation was introduced into ICs of companies is not altogether clear. It is probably the result of the fairly limiting definition of flood, which only takes into account the flooding of the riverside zone by an outflow of a stream and dam failure. Presumably, insurance companies try to encompass inundation of areas outside the riverside zones.

We can conclude that from the matter-of-fact point of view definitions of terms $\mathrm{F}$ and $\mathrm{I}$ in ICs do not completely correspond to the interpretation of these terms in the scientific literature or in the legislative system. ICs are first of all unclear in their consideration of overland flow caused by sheetwash flooding on slopes. This is an important phenomenon occurring in hill and foothill areas. Furthermore, no insurance company recognises flooding of a territory caused by the controlled release of water from dams.

\section{INCLUSION OF FLOOD HAZARD INTO THE INSURANCE MODULES}

Only one insurance company in the SR (Axa) offers insurance for damage caused by F and I individually through supplementary insurance to standard property insurance, and at the same time it does not offer insurance for F and I risk in any other product. All other companies provide insurance packets with different content (number of covered risks) and amounts of insurance coverage for the given risks. Three companies (Uniqa and partially Poštová banka and Wüstenrot) offer only one module, that is, complete property insurance covering all risks in one product. The remaining companies offer several modules of insurance coverage, which differ in the scope of included insurance risks, the price of insurance, and the limits of the claim amounts. With the exception of Allianz and Union, all other companies include the $\mathrm{F}$ and I risks in their basic property insurance packets.

Such a business model of insurance is normally applied when the demand for insurance is in a positive relationship with the risk of loss (adverse selection, [16]). Larger risk generates greater inclination to buy insurance, and the insurer is not able to effectively reflect this correlation in the price of the insurance. Particularly in the case of natural events, it is more economically effective if these risks are part of broader insurance. If the clients want to insure their property against flooding, they have to accept the fact that their insurance premium also includes risks that they do not need/want to insure. 


\section{SCOPE OF PROPERTY INSURANCE}

Property insurance is divided into two basic categories: building insurance and household insurance. In general, the object of building insurance is a building (family house or flat) where damage to fixed (outer and inner) inseparable building elements and coupling connections is reimbursed. The object of household insurance covers the content of a household in a family house, flat, or holiday cottage/house, which serves the operation of the households or meets the needs of the insured or the insured household members. It is possible to contract separate building insurance and separate household insurance.

Particularly if a primary reason for insurance is damage caused by flood hazard, insurance needs to focus also on the protection of property situated outside the building itself. It is important to enquire whether and under what conditions the other buildings situated on the plot belonging to the property, the plot itself (garden), crops/harvest, etc. are the objects of insurance. The majority of insurance companies insure outbuildings (buildings not intended for living in built on solid foundations or firmly attached to the terrain, such as summer houses, garages, farm buildings, and the like). However, plots, crops, greenhouses, and plastic greenhouses are not generally objects of insurance. Aegon is the only insurer that offers insurance of crops grown for private consumption and agricultural produce after harvest within the basic insurance packet as part of household contents. Likewise, one insurance company (Axa) offers the insurance of growths, garden architecture, and greenhouses in its top variant (within building insurance). Three insurance companies (Union, Allianz, and Groupama) offer the option of additional insurance for gardens, plants, and trees, including the harvest, for their basic insurance. A special category is that of yard animals and pets, which are either not included in the property insurance at all (Astra, Ergo, Poštová banka, Union, and Uniqa), or they are insured under the basic household insurance but always with a fixed claim amount (remaining companies).

Concerning the insurance coverage, in the case of insured event caused by F and I the cost of the following plays and an important role: tidying/cleaning and drying of insured things; removal/disposal of the remaining insured things that have been impaired or damaged by insured event; alternative accommodation if the building/household has become inhabitable; storage of insured things in hired premises after the insured event and measures expended to divert/mitigate the imminent insured event.

Before signing the policy in addition to familiarity with scope of insurance, it is necessary to require information about all specific conditions concerning the exclusions and limits of insurance coverage.

\section{EXCLUSIONS AND LIMITS OF FLOOD AND INUNDATION RISK INSURANCE}

Situations when the insurer applies exclusion (property is not insured against F and I risk) or imposes limits to insurance claims (property is insured but the amount of insurance claim is limited) are generally quoted in specific ICs of each company. The following part of the study will be devoted to exclusions from $\mathrm{F}$ and I risk insurance. The question of limits will be treated along with the insurance claims in the next chapter.

Exclusions of insurance coverage in Slovak insurance companies are defined:

- On the basis of flood frequency at the insured place: the insurer will not compensate damage caused by $\mathrm{F}$ if $\mathrm{F}$ occurred at the insured place within 10 years before the policy was contracted (Aegon, Groupama, and partially ČSOB);

- On the basis of $\mathrm{N}$-year maximum discharge, that is, discharge repeated on average once 
every $\mathrm{N}$-years. Insurance does not apply to the damage caused by flooding which is repeated on average less than every 10 years (Allianz, Astra, Union);

- Both exclusions can be applied simultaneously and the insurance does not apply to damage caused by $F$ with a return period on average less of than 20 years and for the insured place where a flood occurred in the last 10 years at least twice before the time of insurance (Axa,Ergo);

- Based on their own definition of the risk area in combination with some of the above-mentioned exclusions: $\check{C} S O B$ does not insure in areas where a place of insurance is situated within 200 metres of a riverbank and its elevation does not surpass $3 \mathrm{~m}$ from the bank. It also does not insure in places which have been hit by F or I within 10 years before conclusion of the policy. Poštová banka requires information concerning the distance of the family house from the nearest stream (more or less than $10 \mathrm{~m}$ ) and whether the building was hit by $\mathrm{F}$ or increasing ground water in 5 years prior to the conclusion of the policy. Generali uses flood maps with the statistical probability of F and I risk. If the system assesses that the place of insurance falls into a zone which has been hit by flooding four or more times in the last 10 years, the building/household cannot be insured against $\mathrm{F}$ and I risk.

The insurance companies Komunálna poistovňa, Kooperatíva, Uniqa, and Wüstenrot did not apply any exclusions in 2015; they insured all areas regardless of flood hazard (some of them with no limits: Wüstenrot and Uniqa, other than some limits to insurance coverage). This is the reason why these companies together with Poštová banka and Generali do not quote any exclusions in their ICs either. In the case of the two companies mentioned last, all relevant information on flood insurance is discovered before the conclusion of contracts and the insured is so notified of the exclusion of insurance coverage at the outset.

However, it is not a rule to inform clients about exclusions of flood risk insurance by insurers who have such exclusions in their ICs. The companies that declare that they inform their clients about the clauses in their ICs based on which they are not obliged to provide an insurance claim or in which claims are limited are Aegon, Axa, Groupama (by word of mouth), and Union (via questionnaire). It should be pointed out here that companies do not pay special attention to the F and I risk, also because this risk is normally part of a packet along with other risks. It is therefore the client's obligation to become thoroughly familiar with the ICs concerning the individual risks. Empirical evidence shows, however, that the policyholders do not read ICs related to insurance restrictions in detail upon signing the contract, and study them only when the insurance event has occurred.

An insurer may also refuse the overall claim/reduce the insurance coverage if the insured fails to fulfil the obligations connected to flood hazard insurance. Some companies impose special obligations concerning protection of property against inundation or flooding. For instance, in places located in the underground floors of buildings, the insured is obliged to have the insured items stored at least $12 \mathrm{~cm}$ (ERGO), $14 \mathrm{~cm}$ (Kooperativa), or $15 \mathrm{~cm}$ (Generali) above the lowest level of the basement floor. Each company also quotes in its general conditions that the policyholder is obliged to prevent the insurance event and to carry out reasonable measures against it or measures that mitigate their scope if the event occurs.

\section{INSURANCE PREMIUM AND CLAIMS}

One of the key factors that plays an essential role in deciding on property insurance is its price - the premium (the amount that customers pay for insurance on their property) and the amount of insurance claim after an insured event. 


\subsection{Amounts of premiums}

The insurance premium, in general, is established depending on the insured value, which should correspond to the value of the insured property (building or household content) at the time the contract is concluded. The insured value for a building is established either by:

- the insurer as the recommended insured value established by calculation based on the parameters of the building;

- the insured, at their own liability or by adaptation of the amount set by the insurer (while it can be grossed up without limits, reductions are only limited by Allianz, that is, up to $20 \%$ of the amount established by the insurer);

- based on an expert testimony, budget, contract, or other document requested by the insurer.

In the case of household content, it is the insured that decides on the insured value and this should correspond to the new value of the group and subgroup of household items at the time the policy is signed. Allianz, as the only insurance company, has the minimum insured value for movable assets established at $€ 6,640$.

If the insurer sets the insured value of a building, its calculation is based on the product of the area in square metres and the internally established coefficient. In the case of family house insurance, the useful (built-up) area is considered, and in the case of flat and household insurance, it is the floor area. Some companies, however, take into account a broader spectrum of factors. For example, apart from the built-up area, Uniqa also uses the realisation of the building (basement, number of storeys, habitable attic) or the territorial factor (capital, regional centre and selected bigger towns, other communes). In Poštová banka, it is the year of final building approval or the year of refurbishment of the family house. Allianz calculates the insured value for a family house taking into account the built-up area, the year of the construction/last refurbishment, the materials used, the number of above-ground storeys, the existence of a basement, and the type of roofing. If a price is being established for a house older than 30 years, $20 \%$ is deducted from the price calculated from other parameters. If the object of insurance is a flat, the above-mentioned companies not only take into account the floor area but also the territorial factor, and Allianz in addition also considers its construction (standard).

Based on the analysis of ICs and on the individual consultations with each insurance company, we can say that the majority of insurance companies in SR practically do not apply the differentiation of premiums based on the level of flood hazard in a given locality. On the one hand, this is because the given locality is assessed by the insurer as a risky one and directly excludes it or because the property insurance against the flood hazard is not concluded separately, but is part of the broader insurance package. Only Axa and Generali differentiate the insurance premium depending on the risk zone (Axa applies the system of coefficients based on the flood event frequency in the place of insurance. Generali makes use of flood maps, which display the statistical probability of flood hazard).

The insurance premium is also modified by what is referred to as a deductible, which is represented by an amount in euros agreed in the policy when the insured participates in insurance claim. Some companies automatically negotiate insurance without a deductible (Allianz, Uniqa, Komunálna poistovňa, Kooperatíva, ČSOB only with the top packet), some of them do it with an obligatory deductible (Aegon, ČSOB, Ergo, Generali, Groupama, Poštová banka, Wüstenrot), although the insured may choose from several options (Astra, Axa, Komunálna poistovňa, Kooperatíva, Union). Aegon and Generali 
also offer zero deductible, albeit with a $5 \%$ and $20 \%$ surcharge added to the insurance, respectively. In the case of an obligatory deductible, some companies offer certain benefits; for instance, Ergo applies a deductible reduced to the amount of $€ 38$ if there was no insurance event during a year, and after two- and three-year periods without claims the amount decreases to $€ 25$ and $€ 13$, respectively. No deductible is required in the case there has been no insurance event in 4 years. Union provides a discount in the case of a deductible of $€ 100$ and $€ 150$.

The insured value is the basis for the calculation of premiums. It should respond to the new value of the insured items, and it is the top limit of an insurance claim as a rule for all insurance events in one insurance year. The insured value does not only influence the amount of a premium, but also the amount of an insurance claim.

\subsection{Insurance claims}

As indicated in the introduction, a distinctly lower compensation of damage caused by flooding reimbursed by an insurance company compared to the actually expended means necessary for the elimination of damage is the most frequent reason for the insured's discontent. In general, the insurance company satisfies the claim up to the insured value quoted in the contract, but always depending on the limits of the insurance claim established for the individual insurance risks and/or insured things according to the chosen insurance module.

In the case of building insurance, the insurance claim limit for property damaged by F or I is set either as the:

- insured value, that is, $100 \%$ of the cost is reimbursed (Aegon, Allianz, Axa, Ergo, Groupama, Komunálna poistovña, Kooperativa, Poštová banka, Astra only in the top packet, Generali only if the building is situated in a minimum F and I risk zone, and Uniqa only in the case of flats);

- some percentage of insured value (Astra, ČSOB, Uniqa in the case of building insurance). Generali's principle is that if the building is situated in an increased $\mathrm{F}$ and I risk zone then there is a limit to the claim amount lower than the insured value. Komunálna poistovña and Kooperativa may cut the insurance claim by $80 \%$ in the case the insurance event was caused by $\mathrm{F}$ or I which occurred more frequently that once in 5 years prior to the date of the event;

- maximum claim limit as it is established and quoted in the contract as a fixed amount (ČSOB, Union, Wüstenrot).

In the case of household insurance, there are more specified items and their reimbursement is defined as some percentage of insured value for household content or a fixed amount in euros is set. Some companies even quote in their conditions a table for all groups of household things. Particular limits to claims are separately set for what is referred to as special movable property (money, jewels, artwork, etc.) or other specific things and equipments (animals, in some companies food articles, tools, sports equipment, electronics, optical equipments).

Moreover, the cuts in insurance claims also occur due to:

- the depreciation of property. If the depreciation or devaluation exceeds a certain percentage or age, the claim amount is cut proportionally. This means that the company does not compensate in the 'new' but in 'time' prices or a limit to the new price of the building/thing is set. 
Time prices are also paid if the things are kept below the terrain level (ČSOB), or for 'special' things such as someone else's things ( $A x a, \check{C} S O B)$, building components, carpets, garments, and shoes (ČSOB), small mechanisms (ČSOB, Komunálna poist'ovňa, Kooperatíva), damaged outbuildings (Komunálna poistovña, Kooperatíva), accessories of buildings with a depreciation of $5 \%$ per year deduction (Komunálna poistovňa, Kooperatíva), vehicles, trailers, boats in a garage, agricultural machines, and instruments kept inside buildings (Uniqa);

- the declaration of other value (underinsurance), a status of the property other than real, or incorrect data in the insurance contract. If at the time of the insurance event the insured value is lower than the real value of the insured item, it is underinsurance, and the insurer may reduce the amount of the claim proportionally of the insured value to the real value of the insured item.

\section{FINAL REMARKS AND CONCLUSION}

If people were sufficiently aware of what the object of insurance is and for what risks the insurance is negotiated when buying insurance, many misunderstandings would be avoided. However, they rather concentrate on the lowest possible premiums and ignore the scope of the insurance coverage, believing that the conclusion of an insurance contract means insurance of any damage caused to their property. Regarding the flood risk insurance, familiarity with the ICs is crucial and necessary. The insured will thus clearly avoid possible frustration in time of claim when it can happen that the building/household is insured against flood hazard but the damage is not compensated either not at all or in a limited rate due to exclusions and limits to insurance. It is therefore important to:

1. Be thoroughly familiar with the object of insurance, the exclusions, and the limits of the insurance claim at the time of concluding the contract.

It is important to have what is and what is not the object of insurance and the situations and cases (risks) for which the insurance is concluded explained, as well as what the specific situations and limits of the insurance claim are.

2. To establish the correct value of the insured items.

It should not be too low (underestimated), or out of the date if the policy was concluded many years ago. It is recommended that the value be set in the way that would enable the client to procure alternative accommodation in the case of an unexpected insurance event that causes total damage. The client should check on the contract condition regularly once every few years and always revalue the contract when the building/household has been refurbished or renewed.

3. Choose an appropriate method of damage repair.

Experience shows that the amount of a claim depends on the method of damage repair. The insurance companies offer options on how to do it. The insured may repair damage by themselves (on a budget) or hire a company for the job. Especially if the case is small damage, the clients may choose the first option. They receive money from the insurance company earlier, albeit usually a smaller amount compared to the second option. As explained by an employee of one unnamed insurance company: 'People who decide to remove damage by themselves or not to repair it at all receive less money, because the insurance company only pays up to the time price. If they hire a contractor and the damaged building has been insured to a new value, and present an invoice to the insurer, the insurance company reimburses it including the price of the work.' According to him, people believe that the first option is more profitable. They estimate the damage, for ex- 
ample at $€ 3,000$, and plan to repair the damage for half that amount, expecting to obtain the other half from the insurer. Of course the reality is different. Clients are advised not to try to gain any surplus through the claim.

\section{ACKNOWLEDGEMENTS}

This article is one of the outputs of the 2/0038/15 project, financially supported by the Scientific Grant Agency of the Ministry of Education, Science, Research and Sport of the Slovak Republic and the Slovak Academy of Sciences (VEGA).

\section{REFERENCES}

[1] APFM (Associated Programme on Flood Management), Integrated Flood Management, APFM technical document no. 1, 2nd edn., World Meteorological Organization and Global Water Partnership: Geneva, 2004.

[2] Lamond, J.E., Proverbs, D.G. \& Hammond, F.N., Accessibility of flood risk insurance in the UK: confusion, competition and complacency. Journal of Risk Research, 12(6), pp. 825-841, 2009. http://dx.doi.org/10.1080/13669870902768614

[3] Thieken, A.H., Petrow, T., Kreibich, H. \& Merz, B., Insurability and mitigation of flood losses in private households in Germany. Risk Analysis, 26(2), pp. 383-395, 2006. http://dx.doi.org/10.1111/j.1539-6924.2006.00741.x

[4] Thieken, A.H., Kreibich, H., Müller, M. \& Merz, B., Coping with floods: preparedness, response and recovery of flood-affected residents in Germany in 2002. Hydrological Sciences Journal, 52(5), pp. 1016-1037, 2007. http://dx.doi.org/10.1623/hysj.52.5.1016

[5] Siegrist, M. \& Gutscher, H., Natural hazards and motivation for mitigation behavior: people cannot predict the affect evoked by a severe flood. Risk Analysis, 28(3), pp. 771-778, 2008. http://dx.doi.org/10.1111/j.1539-6924.2008.01049.x

[6] Holub, M. \& Fuchs, S., Mitigating mountain hazards in Austria: Legislation, risk transfer, and awareness building. Natural Hazards and Earth System Sciences, 9(2), pp. 523-537, 2009.

http://dx.doi.org/10.5194/nhess-9-523-2009

[7] Johnstone, W.M. \& Lence, B.J., Assessing the value of mitigation strategies in reducing the impacts of rapid-onset, catastrophic floods. Journal of Flood Risk Management, 2(3), pp. 209-221, 2009.

http://dx.doi.org/10.1111/j.1753-318X.2009.01035.x

[8] Michel-Kerjan, E. \& Kunreuther, H., Redesigning flood insurance. Science, 333(6041), pp. 408-409, 2011.

http://dx.doi.org/10.1126/science. 1202616

[9] Slovak Insurance Association. Insurance products on the Slovak insurance market, 2015. Online [in Slovak], avaliable at https://www.slaspo.sk/tmp/asset_cache/ link/0000048299/RS\%20SLASPO\%202013\%20-\%20kapitola\%20D\%20-\%20SJ.pdf

[10] Slovak Insurance Association, Annual Report 2013. Chapter D: Slovak Insurance Market in 2013, 2014. Online [in Slovak], available at https://www.slaspo.sk/tmp/ asset_cache/link/0000048267/Poistne $\% 20$ produkty\%20na\%20SK\%20poistnom\%20 trhu\%20k\%203103\%202014\%20na\%20web\%20stranku.pdf 
[11] Solín, L., Madajová, M. \& Skubinčan, P., Mitigating flood consequences: analysis of private flood insurance in the Slovakia. Journal of Flood Risk Management, DOI: 10.1111/jfr3.12191, 2015. http://dx.doi.org/10.1111/jfr3.12191

[12] Madajová, M., Solín, L. \& Michálek, A., Vývoj a priestorová variabilita poistenia obyvatel'stva proti riziku povodne na Slovensku v období 2002 - 2011. Ekonomický časopis, 63(2), pp. 167-187, 2015.

[13] Ward, R.C. \& Robinson, M., Principles of Hydrology, 3rd edn., McGraw-Hill Book Company: London, 1990.

[14] Smith, K. \& Ward, R., Floods: Physical Processes and Human Impacts, John Wiley \& Sons: Chichester, 1998.

[15] Chow, V.T., Hydrologic studies of floods in the United States. International Association of Scientific Hydrological Publications, 42, pp. 134-170, 1956.

[16] Ward, R.C., Floods: A Geographical Perspective, Macmillan: London, 1978.

[17] Act No. 71/2015, Amendment to the Act Flood Protection No. 7/2010, Slovakia [in Slovak].

[18] Act No. 7/2010, Act on Flood Protection No. 7/2010, Slovakia [in Slovak]. 